\title{
UJI EFEKTIFITAS DAUN ALANG-ALANG (IMPERETA CYLINDRICAL) SEBAGAI ANTI NYAMUK ELEKTRIK TERHADAP KEMATIAN NYAMUK AEDES AEGYPTI
}

\author{
Muh. Yusran, Nurhapsa, Abdul Madjid \\ Program Studi Kesehatan Masyarakat Fakultas Ilmu Kesehatan Universitas Muhammadiyah Parepare \\ (muhyusrankembar@gmail.com)
}

\begin{abstract}
ABSTRAK
Setiap tahun ratusan juta kasus penularan penyakit pada manusia melalui serangga yang dikenal dengan Rthropod Borne disease atau sering juga disebut sebagai Vector borne disease telah menimbulkan tantangan kesehatan masyarakat secara global, karena penyebarannya berlangsung secara luas dan cepat. Penyakit Demam Berdarah Dengue masih merupakan salah satu masalah kesehatan masyarakat yang utama di Indonesia. Jumlah penderita dan luas daerah penyebarannya semakin bertambah seiring dengan meningkatkan mobilitas dan kepadatan penduduk. Penelitian ini bertujuan untuk mengetahui perbedaan anti nyamuk elektrik daun alang-alang (Imperata Cylindrical) terhadap kematian nyamuk Aedes aegypti berdasarkan berat konsentrasi daun alang-alang terhadap kematian nyamuk Aedes aegypti dengan 3 kali percobaan pada setiap kelompok perlakuan. Jenis penelitian ini adalah eksperimen semu (Quasi eksperiment) dengan desain penelitian Rancangan Acak Lengkap (RAL). Berdasarkan hasil penelitian yang dilakukan bahwa Kemampuan anti nyamuk elektrik yang paling efektif membunuh nyamuk Aedes aegypti adalah pada konsentrasi 400 gram, dimana persentasi rata-rata membunuh nyamuk dalam waktu 6 jam mampu membunuh 100\% nyamuk Aedes aegypti.
\end{abstract}

\section{Kata Kunci: Efektifitas daun alang-alang, berat konsentrasi Nyamuk Aedes aegypti.}

\section{ABSTRACT}

Every year hundreds of millions of cases of transmission of disease to humans through insects, known as Rthropod Borne disease, or often referred to as Vector borne disease, have posed global health challenges, because the spread is widespread and rapid. Dengue Hemorrhagic Fever is still one of the main public health problems in Indonesia. The number of patients and the area of spread is increasing along with increasing mobility and population density.This study aims to determine the differences in the electric mosquito repellent leaves of alang-alang (Imperata Cylindrical) against the mortality of Aedes aegypti mosquitoes based on the concentration of alang-alang leaf concentration on the death of Aedes aegypti mosquitoes with 3 trials in each treatment group.This type of research is a quasi experiment (Quasi experiment) with a completely randomized design (CRD) design.Based on the results of research conducted that the most effective electric antimosquito ability to kill Aedes aegypti mosquitoes is at a concentration of 400 grams, where the average percentage of killing mosquitoes within 6 hours can kill 100\% of Aedes aegypti mosquitoes

Keywords: Effectiveness of alang-alang leaves, weight of Aedes Aegypti Mosquito concentration. 


\section{PENDAHULUAN}

Setiap tahun ratusan juta kasus penularan penyakit pada manusia melalui serangga yang dikenal dengan Rthropod Borne disease atau sering juga disebut sebagai Vector borne disease telah menimbulkan tantangan kesehatan masyarakat secara global, karena penyebarannya berlangsung secara luas dan cepat. Penyakit yang umumya ditularkan melalui vektor merupakan penyakit endemis pada daerah tertentu antara lain, Demam Berdarah Dengue (DBD), Malaria, Chikungunya, dan Kaki Gajah. Demam Berdarah Dengue adalah penyakit demam akut yang disebabkan oleh virus Dengue, yang masuk ke peredaran darah manusia melalui gigitan nyamuk dari genus Aedes. Aedes aegypti dan Aedes albopictus merupakan vektor utama penularan penyakit DBD.

Penyakit Demam Berdarah Dengue masih merupakan salah satu masalah kesehatan masyarakat yang utama di Indonesia. Jumlah penderita dan luas daerah penyebarannya semakin bertambah seiring dengan meningkatkan mobilitas dan kepadatan penduduk. Demam berdarah pertama kali ditemukan di Indonesia di kota Surabaya pada tahun
1968, dimana ada 58 orang terinfeksi dan 24 diantaranya meninggal dunia (angka kematian : 41,3\%) sejak saat itu, penyakit ini menyebar luas di Indonesia. Departemen Kesehatan Republik Indonesia2009. ${ }^{1}$.

Kota Parepare Sulawesi Selatan dinyatakan dalam keadaan waspada penyakit demam berdarah karna wabahnya akan memuncak pada Februari dengan semakin tingginya curah hujan. Jumlah penderita Demam Berdarah meningkat pada 2014 sebanyak 104 Orang. 1 diantaranya meninggal dunia sedangkan pada tahun 2015 mencapai 149 orang. Saat itu juga seeorang meninggal dunia jumlah terbanyak selalu pada bulan Februari pada Januari 2016 terhadap penderita yang menjalani perawatan itensif di RSUD Andi Makkasau. Profil RSUD Andi Makkasau,2016. ${ }^{2}$

Fogging atau penyemprotan nyamuk salah satu pekerjaan yang dilakukan oleh operator pest control yang sistem pekrjaannya adalah dengan melakukan Fogging (pengasapan) disekitar lingkungan yang sudah ada manusia kena gigitan nyamuk demam berdarah dan mengakibatkan manusia tersebut menjadi sakit. Untuk menghindari 
agar nyamuk demam berdarah tidak bersarang dilingkungan anda diutamakan kebersihan daripada lingkungan dan disarankan dilakukan Fogging (pengasapan) yang dikerjakan oleh badan usaha yang profesional. prima professional siap untuk membantu anda apabila ada terindikasi menderita demam berdarah.

\section{BAHAN DAN METODE}

Penelitian ini berbentuk eksperimen semu (Quasi ekspperiment) yaitu meneliti efektifitas Daun Alang-alang (Imperata cylindrical) dalam pengendalian nyamuk Aedes aegypti. Desain yang di gunakan dalam penelitian ini adalah metode Rancangan Acak Lengkap (RAL) dimana percobaan dilakukan dengan 3 macam perlakuan dan satu control, perlakuan dengan konsentrasi daun Alang-alang 200 gram, 300 gram, 400 gram serta dilakukan 3 kali pengulangan.

Tabel 1. Bilangan acak lengkap

\begin{tabular}{|c|c|c|}
\hline K11 & K01 & K31 \\
\hline K22 & K33 & K02 \\
\hline K32 & K03 & K12 \\
\hline K23 & K32 & K21 \\
\hline
\end{tabular}

\section{Ket:}

K01 : Konsentrasi (-) pengulangan 1

K02 : Konsentrasi (-) pengulangan 2

K03 : konsentrasi (-) pengulangan 3
K11 : Konsentrasi 200 gram pengulangan 1

K12 : Konsentrasi 200 gram pengulangan 2

K13 : Konsentrasi 200 gram pengulangan 3

K21 : Konsentrasi 300 gram pengulangan 1

K22 : Konsentrasi 300 gram pengulangan 2

K23 : Konsentrasi 200 gram pengulangan 3

K31 : Konsentrasi 400 gram pengulangan 1

K32 : Konsentrasi 400 gram pengulangan 2

K33 : Konsentrasi 400 gram pengulangan 3

\section{HASIL}

Penelitian mengenai uji efektifitas daun alang-alang (Imperata cylindrical) sebagai anti nyamuk elektrik terhadap kematian nyamuk Aedes aegypti telah di lakukan pada tanggal 20 juni 2018. Pengambilan sampel nyamuk dilakukan dengan menangkap jentik nyamuk Aedes aegypti dengan menggunakan ovitrap yang dipasang di kost-kosan Lembah Harapan Soreang Kota Parepare dengan meletakkan pada tempat-tempat habitat nyamuk Aedes aegypt, seperti tempat yang lembab, sedikit cahaya matahari atau memiliki intensitas cahaya yang rendah. Jumlah sampel nyamuk uji yang digunakan dalam penelitian ini adalah sebanyak 220 ekor nyamuk Aedes aegypti, dimana setiap percobaan menggunakan 60 ekor nyamuk dan setiap perlakuan digunakan 20 ekor nyamuk sebagai sampel dalam penelitian. Sedangkan daun alang- 
alang diperoleh di Baraka Kab.Enrekang dengan konsentrasi daun alang-alang yang berbeda-beda 200 gram, 300 gram, 400 gram. Untuk pengujian nyamuk menggunakan daun alang-alang dilakukan di laboratorium.
Hasil penelitian adalah hasil-hasil yang diperoleh dari percobaan yang dilakukan dalam penelitian. Berikut, hasil uji statistik yang dilakukan pada tiga kelompok berat konsentrasi daun alangalang (Imperata cylindrical). dengan 3 kali percobaan.

Tabel 2. Jumlah minimum, maximum dan rata-rata jumlah nyamuk yang mati pada berat konsentrasi alang-alang (Imperata cylindrical) dalam 3 kali percobaan.

\begin{tabular}{c|c|c|c|c}
\hline \multirow{2}{*}{ Konsentrasi } & \multicolumn{3}{|c}{ Jumlah nyamuk Yang mati } \\
\cline { 2 - 5 } & Std. Deviation & Minimum & Maximum & Rata-rata \\
\hline 200 gram & 43001 & 11.25 & 12.00 & 11.75 \\
\hline 300 gram & 25000 & 16.00 & 16.50 & 16.25 \\
\hline 400 gram & 28868 & 17.75 & 17,75 & 18.03 \\
\hline Total & 2.83701 & 11.25 & 49.00 & 15.36 \\
\hline
\end{tabular}

Sumber: data primer

Tabel 3. Perbedaan jumlah nyamuk yang mati pada berat konsentrasi daun alang-alang (Imperata cylindrical) 200 gram, 300 gram, dan 400 gram

\begin{tabular}{lcrrrr}
\hline & Sum of Squares & Df & Mean Square & F & Sig. \\
\hline Between Groups & 63.722 & 2 & 31.861 & 286.750 & .000 \\
Within Groups & .667 & 6 & .111 & & \\
\hline Total & 64.389 & 8 & & & \\
\hline *ANOVA test & & & & &
\end{tabular}

Tabel 2 menunjukan bahwa berat konsentrasi daun alang-alang (Imperata cylindrical) pada konsentrasi 200 gram dalam 3 kali percobaan nyamuk mati minimun 11.25 ekor, maximum 12.00 ekor dengan rata-rata kematian 11.75 ekor nyamuk. Berat konsentrasi 300 gram dalam 3 kali percobaan nyamuk mati minimum 16.00 ekor, maximum 16,50 ekor dengan rata-rata kematian 16.25 ekor nyamuk. Dan pada konsentrasi 400 gram dalam 3 mkali percobaan nyamuk mati minimum 17.75 ekor nyamuk, maximum 
17,75 ekor nyamuk dengan raata-rata kematian 18.03 ekor nyamuk.

Tabel 3 menunjukkan bahwa uji statistic menggunakan ANOVA test pada derajat kepercayaan $95 \%$ menunjukan bahwa adanya perbedaan bermakna pada kematian nyamuk pada konsentrasi daun alang-alang (Imperata cylindrical) 200 gram, 300 gram, dan 400 gram dengan nilai $\quad \mathrm{p}=0.000 \quad(\mathrm{p} \leq 0,005)$. Untuk mengetahui perbedaan kemampuan antara kelompok, maka dilakukan uji lanjut dengan menggunakan uji Duncan pada table 3 berikut ini.

Tabel 4. hasil uji Duncan

Efektifitas Anti nyamuk Elektrik Daun Alang-alang (Imperata cylindrical)

\begin{tabular}{|l|ll|c|c|c} 
Duncan $^{\mathrm{a}}$ & $\begin{array}{l}\text { Konsentrasi alang-alang } \\
\text { (Imperata cylindrica) }\end{array}$ & $\mathrm{N}$ & \multicolumn{3}{|c}{ Subset For Alpha $=0.05$} \\
\cline { 2 - 6 } & 200 gram & 3 & 11.7500 & & 3 \\
\cline { 2 - 6 } & 300 gram & 3 & & 16.2500 & \\
\cline { 2 - 6 } & 400 gram & 3 & & & 18.0833 \\
\cline { 2 - 6 } & & & 1.000 & 1.000 & 1.000
\end{tabular}

Means for groups in homogeneous subsets are displayed.

a. Uses Harmonic Mean Sample Size $=3.000$.

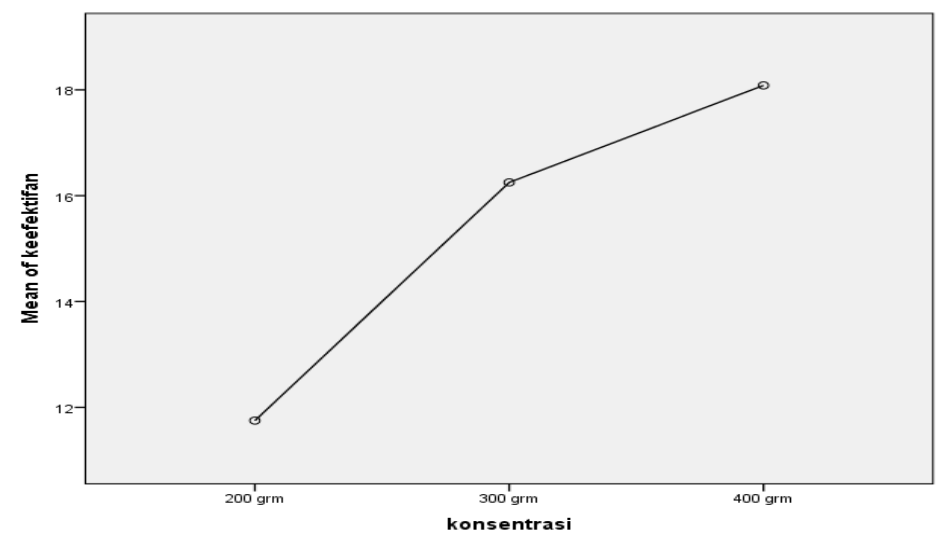

Gambar 1. Grafik rata-rata jumlah nyamuk Aedes aegypti yang mati berdasarkan berat konsentrasi daun alang-alang (Imperata cylindrical). 


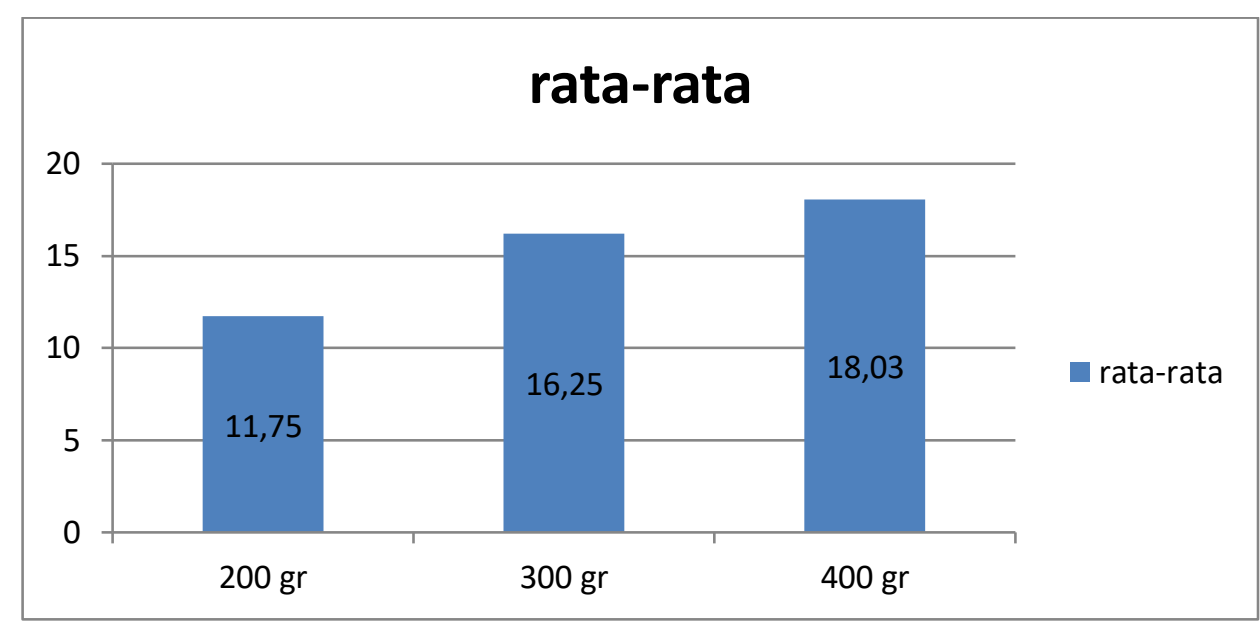

Gambar 2. Diagram rata-rata jumlah nyamuk Aedes aegypti yang mati berdasarkan berat konsentrasi daun alang-alang (Imperata cylindrica).

Berdasarkan data pada table 4 hasil uji statistic lanjutan menggunakan uji Duncan menunjukkan bahwa terdapat perbedaan nyata pada jumlah nyamuk yang mati pada setiap berat konsentrasi daun alang-alaang (Imperata cylindrical) terhadap kematian nyamuk Aedes aegypti.

Berdasarkan grafik pada gambar 1, menunjukkan bahwa rata-rata kemampuan anti nyamuk elekterik daun alang-alang (Imperata cylindrical) antara berat konsentrasi 200 gram sebanyak 11.75 ekor nyamuk, konsentrasi 300 gram sebanyak 16.25 ekor nyamuk, dan konsentrasi 400 gram sebanyak 18.03 ekor nyamuk.

Hasil penelitian menunjukkan, ternyata ada perbedaan kemampuan berat konsentrasi daun alang-alang (Imperata cylindrica) terhadap kematian nyamuk Aedes aegypti. Hal ini terbukti dari hasil uji statistic menggunakan ANOVA test diperoleh nilai $\mathrm{p} \leq 0,05$ dengan demikian Ho ditolak yang berarti ada perbedaan yang bermakna berat konsentrasi daun alangalang (Imperata cylindrical) terhadap kematian nyamuk Aedes aegypti pada tingkat kepercayaan 95\% dengan $\mathrm{p}=0,00$ adalah terbukti signifikan.

Berdasarkan diagram pada gambar 2, dapat diketahui bahwa ada perbedaan antara berat konsentrasi daun alang-alang (Imperata cylindrical) terhadap kematian nyamuk Aedes aegypti. Persentase ratarata kematian nyamuk pada masingmasing konsentrasi daun alang-alang (Imperata cylindrical), untuk 200 gram persentase rata-rata nyamuk yang mati 
pada 6 jam sebanyak 40\%, konsentrasi 300 gr persentase rata-rata kematian nyamuk pada 6 jam sebanyak $87,5 \%$, dan pada konsentrasi 400 gr persentase rata-rata kematian pada 6 jam sebanyak 100\%.

\section{PEMBAHASAN}

Aedes aegypti merupakan spesies nyamuk yang hidup di daerah tropis dan merupakan vektor utama penyakit demam berdarah yang hidup aktif di siang hari dan lebih senang mengisap darah manusia. Aedes aegypti merupakan ordo diptera yang termasuk dalam klasifikasi serangga (insecta) pengganggu yang menyebarkan peyakit dan menyebabkan gangguan kesehatan bagi manusia dengan spesies yang sangat banyak. Namun tidak semua spesies perlu diwaspadai karena beberapa diantaranya tidak menimbulkan efek yang serius bagi kesehatan manusia. Adapun penyakit yang dapat ditularkan oleh jentik nyamuk Aedes aegypti tersebut berupa infeksi saluran pencernaan, infeksi pada mata dan infeksi pada kulit. Upaya pengendalian jentik nyamuk Aedes aegypti telah banyak dilakukan.

Berdasarkan hasil penelitian yang telah dilakukan, maka dapat dikatakan bahwa berat konsentrasi daun alang-alang (Imperata cylindrical) sangat berpengaruh terhadap tingkat kematian nyamuk aedes aegypti hal ini dikarenakan kandungan asam sitrat yang ada pada daun alng-alang (Imperata cylindrical). Semakin tinggi kandungan asam sitrat pada anti nyamuk elektrik maka tingkat kematian nyamuk Aedes aegypti akan semakin cepat.

Table 2 menunjukan bahwa berat konsentrasi daun alang-alang (Imperata cylindrical) pada konsentrasi 200 gram dalam 3 kali percobaan nyamuk mati minimun 11.25 ekor, maximum 12.00 ekor dengan rata-rata kematian 11.75 ekor nyamuk. Berat konsentrasi 300 gram dalam 3 kali percobaan nyamuk mati minimum 16.00 ekor, maximum 16,50 ekor dengan rata-rata kematian 16.25 ekor nyamuk. Dan pada konsentrasi 400 gram dalam 3 mkali percobaan nyamuk mati minimum 17.25 ekor nyamuk, maximum 49.00 ekor nyamuk dengan raata-rata kematian 18.03 ekor nyamuk. Data tersebut menunjukan bahwa berat konsentrasi daun alang-alang (Imperata cylindrical) 200 gram membutuhkan waktu yang paling lama dalam membunuh nyamuk.

Table 3 menunjukkan bahwa uji statistic menggunakan ANOVA test pada derajat kepercayaan 95\% menunjukan bahwa adanya perbedaan bermakna pada 
kematian nyamuk pada konsentrasi daun alang-alang (Imperata cylindrical) 200 gram, 300 gram, dan 400 gram dengan nilai $p=0.000 \quad(p \leq 0,005)$. Hal ini berdasarkan perbedaan berat konsentrasi daun alang-alang (Imperata cylindrical) terhadap kematian nyamuk, dimana daun alang-alang dengan konsentrasi 400 gram lebih cepat bereaksi membunuh nyamuk. Hal ini disebabkan karna perbedaan berat konsentrasi daun alang-alang (Imperata cylindrical) lebih banyak mengandung asam sitrat dari konsentrasi 200 gram dan 300 gram. Hal ini membuktikn bahwa semakin berat konsentrasi daun alangalang (Imperata cylindrical) maka semakin banyak pula kandungaan asam sitram dan semakin cepat pula anti nyamuk elektrik bereaksi terhadap nyamuk.

Hasil penelitian ini menunjukkan bahwa berat konsentrasi daun alng-alang (Imperata cylindrical) sangat berpengaruh terhadap kematian nyamuk Aedes aegypti semakin tinggi kandungan asam sitrat pada anti nyamuk elektrik maka tingkat kematian nyamuk aedes aegypti semakin cepat terbukti pada hasil penelitian ini menunjukan bahwa berat konsentrasi daun alang-alang (Imperata cylindrical) pada konsentrasi 200 gram, konsentrasi 300 gram, konsentrasi dan 400 gram. Konsentrasi yang paling efektif digunakan yakni pada konsentrasi 400 gram dengan persentase kematian nyamuk $100 \%$ pada 6 jam setelah perlakuan. Sehingga daun alang-alang (Imperata cylindrical) ini sangat efektif digunakan dalam pengendalian nyamuk Aedes aegypti karena daun alang-alang mengandung asam sitram yang merupakan musuh bagi serangga karena menyerang saluran pernapasan bagi nyamuk. Selain itu anti nyamuk elektrik ini juga tidak mengancam kesehatan dan keselamatan manusia serta tidak merusak lingkungan sekitar sehingga dibutuhkan upaya untuk menyampaikan dan memberitahu kepada masyarakat akan manfaat daun alang-alang (Imperata cylindrical) sebagai anti nyamuk elektrik terhadap kematian nyamuk aedes aegypti. Masyarakat dapat memamfaatkan daun alang-alang (Imperata cylindrical) ini sebagai anti nyamuk elektrik yang ramah lingkungan.

\section{KESIMPULAN DAN SARAN}

Berdasarkan penelitian dan uji statistik yang telah dilakukan maka dapat ditarik kesimpulan sebagai berikut, Ada perbedaan kemampuan berat konsentrasi daun alang-alang (Imperata cylindrical) 
terhadap kematian nyamuk Aedes aegypti. Berat konsentrasi 400 gram yang paling efektif dalam membunuh nyamuk Aedes aegypti rata-rata 18,08 ekor nyamuk dalam 6 jam setelah perlakuan. Disarankan kepada Bagi masyarakat, sebaiknya memanfaatkan daun alang-alang sebagai anti nyamuk elektrik dalam memberantas nyamuk Aedes aegypti penyebab Demam Berdarah Dangue (DBD) karena tumbuhan alang-alang (Imperata cylindrical) mudah didapatkan dan pembuatan anti nyamuk tidak membutuhkan waktu yang lama. Bagi instansi kesehatan, memberikan intervensi bagi masyarakat agar menggunakan daun alang-alang (Imperata cylindrical) sebagai anti nyamuk elektrik untuk memberantas nyamuk aedes aegypti karena tumbuhan alang-alang (Imperata cylindrical) ini efektif digunakan untuk memberantas nyamuk aedes aegypti. Bagi peneliti selanjutnya dapat mengaplikasikan ditempat pada kandang yang lebih luas dan menamba sampel nyamuk Aedes aegypt untuk mengetahui efektifitas daun alang-alang (Imperata cylindrical) sebagai anti nyamuk elektrik terhadap kematian nyamuk Aedes aegypti dan menguji jenis nyamuk yang lain dan menggunakan tanaman herbal yang berbeda yang dapat membunuh nyamuk, kemudian menambah wangi-wangian pada anti nyamuk seperti kulit jeruk, bunga lavender dan tanaman lain yang tidak disukai nyamuk.

\section{DAFTAR PUSTAKA}

1. Departemen Kesehatan Republik Indonesia Demam Berdarah Penyebab Kematian Terbesar di RI. Jakarta: Depkes RI; 2009.

2. Profil RSUD Andi Makkasau. Parepare: RSUD Andi Makkasau; 2016.

3. Ariani, Nana.2005. Pemanfaatan Akar Alang- Alang Menjadi Produk Olahan Sirup Dan Bahan Campuran Pembuatan Kertas Daur Ulang Di Desa Bandar Khalifah. Medan: Universitas Negri Medan.

4. Arianti, R. 2012. Aktivitas Hepatoprotektor Dan Toksisitas Akut Ekstrak Akar Alang-Alang (Imperata cylindrica). Skripsi. Bogor: Jurusan Biokimia FMIPA IPB.

5. Asih Sulistiani, 2015. Effectiveness of essensial oil as larvacides on aedes Aegypti. Universitas Lampung.

6. Asna Umar, 2014 Sistem Daur Ulang Anti Nyamuk Elektrik Dengan Menggunakan Kulit Durian (Durio Zibethinus Murr) Untuk Pengendalian 
Nyamuk Aedes Aegypti. Universitas

Negeri Gorontalo.

7. Bagas, Rasyid. Ekologi Hewan Tentang "Nyamuk Aedes aegypti, Anopheles sp, dan Culex sp.2012. Available at

Http://Bagasrasid89./2012/12/Makala

h-Nyamuk-Aedes-Aegypti-

Anopheles.Html. (Akses 22 Mei 2017)

8. Candra, A. Demam Berdarah Dengue:

Epidemiologi, Patogenesis, dan Faktor

Risiko Penularan, Aspirator. 2010.

Volume 2, No 2.

9. Diah Dhianawaty. 2015. Kandungan

Total Polifenol dan Aktivitas Anti

Oksidan Dari Ekstrak Metanol Akar

Alang-Alang (Imperata cylindrical).

10. Inci Rukmana, 2015. Efektivitas

Ekstrat Kulit Buah Jeruk Purut (Citrus

Hyysstrix) Terhadap Kematian Larva

Aedes Aegypti.

11. Indri Ramayanti, Kamalia Layal , Putri Utami Pratiwi, 2017. Efektivitas

Ekstrak Daun Kemangi (Ocimum basilicum) Sebagai Bioinsektisida

Sediaan Anti nyamuk Bakar Terhadap Kematian Nyamuk Aedes aegypti.

12. Kementerian Kehatan RI. Profil Pengendalian Penyakit dan
Penyehatan Lingkungan Tahun 2014. Jakarta; 2015.

13. WHO. Panduan Lengkap Pencegahan dan Pengendalian Dengue dan Demam Berdarah Dengu. Jakarta : ECG; 2004.

14. Kementerian Kesehatan RI. Buletin Jendela Epidemiologi Demam Berdarah Dengue. Jakarta: Kementerian Kesehatan; 2010.

15. Kementerian Kesehatan RI. 2010. Peraturan Menteri Kesehatan Republik Indonesia. Nomor 374/Menkes/Per/IaII/2010 Tentang Pengendalian Vektor.

16. Nurmeti, 2017. Implementasi ekstrat kulit durian (durian zibethinus) terhadap kematian larva nyamuk Aedes Aegypti

17. Taviv, Y. Efektivitas Ikan Cupang (Ctenops vittatus) dalam Pengendalian Larva dan Daya Tahannya terhadap Temephos (Uji Laboratorium dan Lapangan). Jurnal Ekologi Kesehatan Badan Litbang Depkes RI. 2007: Vol 6, No.2 Litbangkes Jakarta

18. Vinaliza, Tuti Wiyati, Dolih Gozali, 2014. Pembuatan Dan Uji Aktivitas Sediaan Obat Nyamuk Elektrik Dari Bunga Plumeria Acuminate W.T Ait. 
19. Widya Dwi Qinahyu, Widya Hary Cahyati, 2016. Uji Kemampuan Anti Nyamuk Alami Elektrik Mat Serbuk Bunga Sukun (Artocarpus Altili)
20. WHO. Panduan Lengkap Pencegahan dan Pengendalian Dengue dan Demam Berdarah Dengu. Jakarta : ECG; 2004. 